\title{
PENINGKATAN DAYA SAING USAHA MIKRO ANGGOTA PPKM KABUPATEN BANDUNG MENGGUNAKAN MODUL SCORE ILO
}

\author{
Fernando Mulia ${ }^{1^{*}}$ \\ Fakultas Ekonomi, Universitas Katolik Parahyangan \\ email: fernando@unpar.ac.id \\ Cerry Marlencia ${ }^{2}$ \\ Fakultas Ekonomi, Universitas Katolik Parahyangan \\ email:6031801123@student.unpar.ac.id
}

\begin{abstract}
Competition nowadays requires companies to continuously anticipate by adapting with changes in the business environment. When a company unable to adjust, there is a possibility that the company will be less competitive than other companies. Changes in political, economic, social, cultural, and technological conditions are crucial for constant attention. Companies are expected to always respond to changes that occur, including UMKM (MSME).

MSMEs in Bandung Regency have an Organization, called "Paguyuban Pengusaha Kecil Menengah (PPKM) Kabupaten Bandung", West Java, which has members with various types of businesses. Based on the results of interviews with the staff of the Cooperatives and SMEs Service and the Chairman of the UMKM Association of Bandung Regency, the problems that often occur in the UMKM environment there are quite diverse, such as problems in the production process, quality of goods, marketing, financial records, which lead to low competitiveness.

Sustaining Competitive and Responsible Enterprises (SCORE) program from the International Labour Organization (ILO) is a program that aims to increase productivity, cooperation, and workers' commitment to the company. This program will increase competitiveness, starting with improvements in the internal company. The UNPAR SCORE program which was held in 2020 is the 4th batch and in its implementation experienced the COVID19 Pandemic, so it was forced to undergo various adjustments. There were several conditions that caused some participants not to survive, but out of 33 participants, 20 MSMEs completed the SCORE UNPAR Batch 4 program until the final presentation.
\end{abstract}

Keywords: Competitiveness, MSME, SCORE

\section{ABSTRAK}

Persaingan yang terjadi menuntut para pelaku usaha untuk terus menerus mengantisipasi dengan melakukan penyesuaian seiring perubahan pada lingkungan usaha. Bila pelaku usaha tidak dapat melakukan penyesuaian usaha, maka terdapat kemungkinan usahanya akan kalah bersaing dibandingkan perusahaan lain. Perubahan kondisi politik, ekonomi, sosial, budaya dan juga teknologi sangan krusial untuk senantiasa diperhatikan. Para pelaku usaha diharapkan dapat senantiasa merespons perubahan yang terjadi, termasuk didalamnya pelaku usaha yang masuk dalam kategori UMKM.

UMKM di Kabupaten Bandung memiliki sebuah wadah yaitu Paguyuban Pengusaha Kecil Menengah (PPKM) Kabupaten Bandung, Jawa Barat yang memiliki anggota dengan berbagai jenis usaha. Berdasarkan hasil wawancara dengan staf Dinas Koperasi dan UKM dan Ketua PPKM Kabupaten Bandung, permasalahan yang banyak terjadi di lingkungan UMKM di sana adalah cukup beragam, seperti masalah proses produksi, kualitas barang, pemasaran, pencatatan keuangan, yang berujung pada rendahnya daya saing.

* Koresponden 
Program Sustaining Competitive and Responsible Enterprises (SCORE) dari International Labour Organization (ILO) adalah sebuah program yang bertujuan meningkatkan produktivitas, kerja sama, serta komitmen pekerja terhadap perusahaan. Program ini akan meningkatkan daya saing, dimulai dengan perbaikan pada internal perusahaan. Program SCORE UNPAR yang diselenggarakan pada Tahun 2020 merupakan batch ke 4 dan pada pelaksanaannya mengalami Pandemi COVID19, sehingga terpaksa mendapatkan berbagai penyesuaian. Terdapat beberapa kondisi yang menyebabkan beberapa peserta tidak bertahan, namun dari 33 peserta yang ada 20 UMKM menyelesaikan program SCORE UNPAR Batch 4 hingga presentasi akhir.

Kata kunci: Daya Saing, SCORE, UMKM

\section{PENDAHULUAN}

UMKM di Indonesia umumnya mengalami permasalahan pada proses produksi, konsistensi kualitas barang, pemasaran yang kurang tepat sasaran, pencatatan keuangan yang secara kumulatif menyebabkan rendahnya daya saing di pasar.

Beberapa permasanlah yang teridentifikasi pada tahapan diskusi adalah:

- Permasalahan Pengelolaan Perusahaan Secara Umum

Masalah Komunikasi dan Kerja Sama di tempat kerja sering kali menjadi salah satu permasalahan yang dapat mengganggu pengelolaan perusahaan dan dapat dengan mudah menjadi masalah yang mengakibatkan perusahaan tidak dapat bersaing dengan perusahaan lain, karena secara internal perusahaan belum dapat beroperasi dengan baik.

- Pengelolaan Produksi dan Kualitas Produksi pada UMKM memiliki masalah yang beragam, namun umumnya masalah konsistensi produksi menjadi kendala yang masih perlu diselesaikan oleh perusahaan. Selain itu UMKM masih kesulitan dalam menentukan kualitas dari produk yang dihasilkan, termasuk di dalamnya bagaimana menjaga kualitas produk yang dihasilkan. Setelah Kualitas, masalah selanjutnya yang perlu diselesaikan adalah masalah produktivitas, bagaimana produktivitas dapat ditingkatkan sehingga produk yang dihasilkan memiliki daya saing yang tinggi di pasar. Masalah Produktivitas di UMKM kada terjadi karena tempat produksi yang masih menyatu dengan tempat tinggal. Hal ini perlu disiasati dengan baik agar dapat mengoptimalkan tempat yang tersedia, namun dapat dimanfaatkan secara baik.

- Pemasaran

UMKM umumnya belum dapat mendefinisikan dengan jelas target pasar yang akan dituju, serta bagaimana menggapai target pasar tersebut, sehingga UMKM tidak fokus dalam menggarap pasar yang tepat. Minimnya inovasi serta sentuhan teknologi juga kadang menyebabkan cakupan pasar yang dikerjakan oleh UMKM tidak berkembang.

- Keuangan

Dalam mengelola keuangan, pelaku UMKM sering tidak melakukannya dengan cermat, penentuan harga jual sering tidak disertai dengan perhitungan yang matang, sehingga dapat terjadi kondisi harga jual berada di bawah HPP, sehingga UMKM menderita kerugian setiap kali terjadi penjualan.

Mitra pada kegiatan Abdimas SCORE UNPAR Batch 4 adalah UMKM yang tergabung pada Paguyuban Pengusaha Kecil Menengah (PPKM) Kabupaten Bandung, Jawa Barat. PPKM merupakan sebuah wadah bagi para pelaku usaha yang di dalamnya terdiri dari berbagai jenis usaha yang berasal dari seluruh penjuru kecamatan yang ada di Kabupaten 
Bandung. Tujuan dibentuknya PPKM adalah menjadi mitra pemerintah Kabupaten Bandung dalam hal pemberdayaan para pelaku usaha yang masuk dalam kategori mikro, kecil maupun menengah, serta bersinergi dengan seluruh Satuan Kerja Perangkat Daerah (SKPD) yang terkait dengan pembinaan UMKM (Humas Pemkab Bandung, 2017). Pada kegiatan ini terdapat 33 UMKM yang menjadi peserta SCORE UNPAR.

SCORE UNPAR menggunakan pendekatan pelatihan Sustaining Competitive and Responsible Enterprises (SCORE) yang diinisiasi oleh International Labour Organization (ILO) (SCORE Indonesia, 2021). Sejak tahun 2018 UNPAR telah resmi menjadi implemting partner dari program SCORE di Indonesia (International Labour Organization, 2020). Pada tiga kali batch pelaksanaan SCORE UNPAR yang telah dilakukan sebelumnya, para peserta merasakan manfaat dari program ini (Adriani, et al., 2018).

Program SCORE UNPAR bertujuan membantu peserta untuk dapat beradaptasi dengan perubahan lingkungan yang sangat dinamis yang mempengaruhi dunia usaha.

\section{METODE PELAKSANAAN}

Dalam pelaksanaannya SCORE UNPAR menggunakan pendekatan pelatihan (workshop) yang dikombinasikan dengan pendampingan (coaching) untuk setiap peserta kegiatan. SCORE UNPAR dimulai dengan pelaksanaan sosialisasi. Pada tahapan sosialisasi diundang lebih dari 50 UMKM yang tergabung pada PPKM Kabupaten Bandung untuk mendengarkan pemaparan mengenai program SCORE UNPAR dan juga testimoni dari para peserta yang telah mengikuti pada batch sebelumnya. Pada kegiatan sosialisasi, UMKM diminta untuk mempertimbangkan apakah siap dan mampu untuk menjaga komitmen tetap mengikuti program selama kurang lebih direncanakan selama 3 bulan.

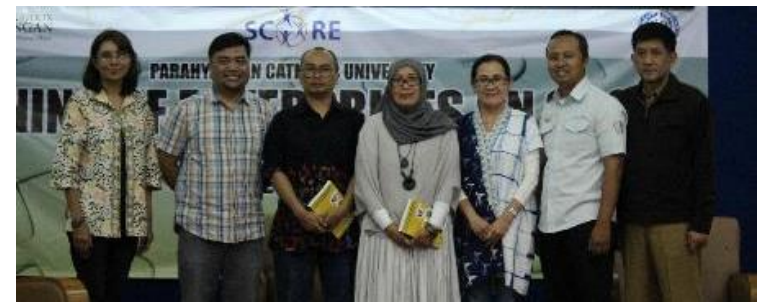

Gambar 1. Tahapan Sosialisasi SCORE UNPAR 2020

Tahapan selanjutnya adalah Baseline Assessment. Pada tahap ini para coach akan mengunjungi dan melakukan penilaian awal kondisi usaha dari peserta yang telah menyatakan komitmennya.

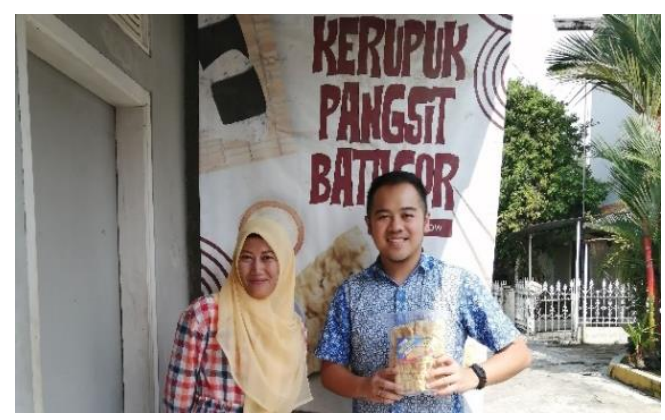

Gambar 2. Baseline Assessment di Tempat Produksi Peserta

Setelah Baseline Assessment, tahapan selanjutnya adalah workshop. Terdapat 4 workshop dengan masing-masing terdiri dari 4 sesi. Di antara workshop terdapat sesi coaching dan kunjungan ke lokasi peserta, jumlah dan waktu pada prinsipnya di sesuaikan dengan kebutuhan dan kesiapan peserta. SCORE UNPAR ditutup dengan presentasi akhir, dimana pada tahapan ini peserta akan mempresentasikan perubahan dan perbaikan yang terjadi di hadapan para Trainer, Coach dan pihak Dinas Koperasi dan UMKM.

Dalam pelaksanaannya tim pengabdi dibantu oleh beberapa mahasiswa yang turut serta membantu proses administrasi, jalannya workshop dan juga berperan aktif dalam menjalankan proses coaching dan ikut dalam proses pendampingan dan memberikan masukkan untuk perbaikan bagi peserta. 


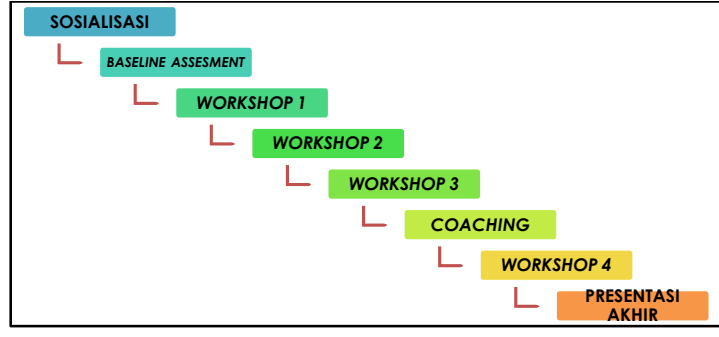

Gambar 3. Tahapan pelaksanaan SCORE UNPAR 2020

Pada awalnya Rencana pelaksanaan SCORE UNPAR batch 4 adalah dimulai pada Februari 2020 dan berakhir pada awal April 2020. Tahapan Sosialisasi, Baseline Assessment, Workshop 1, Workshop 2, Workshop 3 dan Coaching telah berhasil dilakukan tepat pada waktunya.

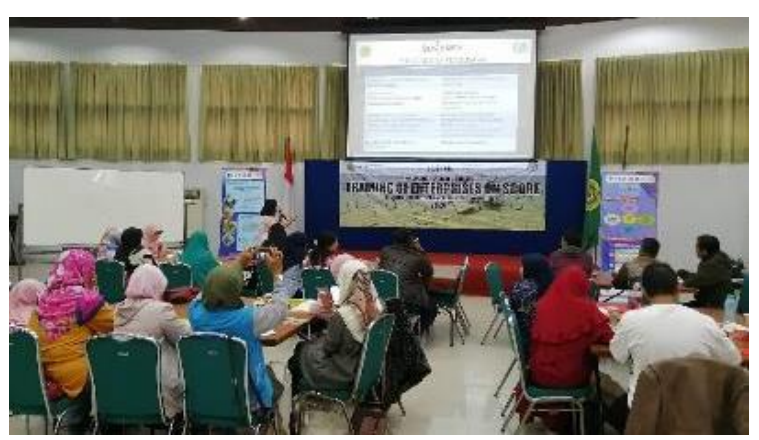

Gambar 4. Workshop 1, Februari 2020

Pada tanggal 15 Maret 2020, pemerintah Indonesia menetapkan kondisi darurat terkait pandemi COVID 19. Hal ini menyebabkan rencana yang telah disusun sebelumnya harus mengalami penyesuaian yang signifikan. Tidak hanya jadwal yang disesuaikan, namun metode penyampaian pun perlu disesuaikan. Setelah melakukan pengamatan dan komunikasi intens dengan peserta selama 1 bulan, tim mendapati bahwa pandemi COVID 19 dan implikasinya termasuk PSBB (Pembatasan Sosial Berskala Besar) telah memorak-porandakan dunia usaha dan tidak terkecuali UMKM. Beberapa peserta diketahui terpaksa berhenti menjalankan usaha karena pasar yang sangat mendadak hilang. Dalam kondisi tersebut tim pengabdi mengambil langkah untuk menambahkan sesi tambahan yaitu Motivational Training. Ini adalah pertama kalinya program SCORE UNPAR diselenggarakan secara daring dengan menggunakan media Zoom dengan cadangan streaming pada platform YouTube.

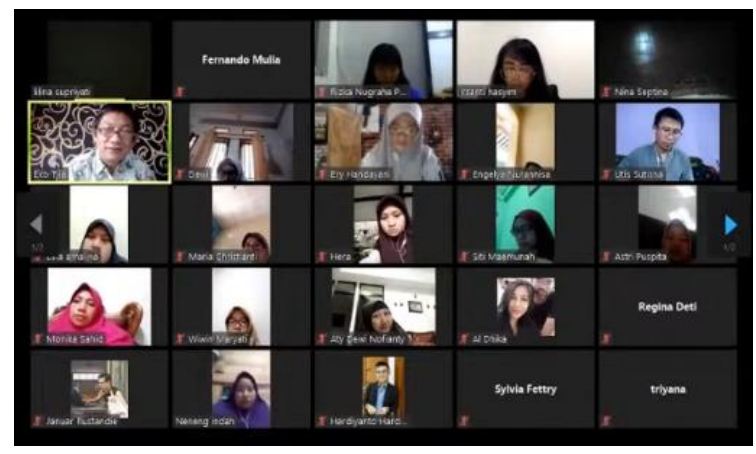

Gambar 5. Motivational Training, April 2020

Setelah sesi Motivational Training, workshop materi SCORE dilanjutkan namun dengan penyesuaian, yang umumnya dalam 1 workshop terdapat 4 sesi, maka setiap workshop hanya diisi 1 sesi, mengingat keterbatasan daya tahan peserta dalam menggunakan media daring.

Pada Program SCORE UNPAR batch 4 diakhiri denga pelaksanaan presentasi akhir. Dari 33 peserta yang mengikuti program, hanya tersisa 20 peserta yang berhasil menyelesaikan program hingga tahap akhir. 13 peserta lain mengundurkan diri dengan berbagai kendala yang dihadapi.

\section{HASIL DAN PEMBAHASAN}

Program SCORE UNPAR batch 4 melaksanakan 3 workshop secara luring, dan ditambah dengan sesi workshop online dengan total 16 sesi ditambah dengan sesi Motivational Training. Sesi yang dilaksanakan adalah: Kerjasama dan Berbagai Informasi; 5S dan Layout; Hygiene dan K3; Identitas dan Segmen Pasar; Budaya Kualitas; Eliminasi Pemborosan; Pembukuan Sederhana; Perhitungan HPP; Pemasaran Dasar; Inovasi dan Pengembangan Produk; Packaging; Pemasaran Digital; Pemasaran Prima; Mutu Layanan; Manajemen Insani; dan Mengukur Perubahan. Dari setia 
sesi yang diselenggarakan peserta diminta untuk melakukan perbaikan yang sesuai dan dapat diaplikasikan pada usaha, sesuai dengan kemampuan.

Perubahan secara signifikan umumnya terjadi pada lantai produksi, lantai produksi menjadi lebih tertata dengan baik dan memiliki tingkat keamanan dan higienis yang lebih tinggi dari sebelumnya.

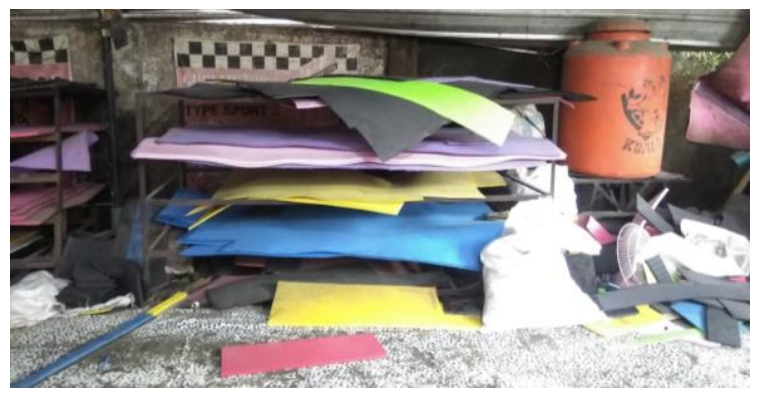

\section{Gambar 6. Penyimpanan Bahan Baku Sebelum mengikuti Program SCORE UNPAR}

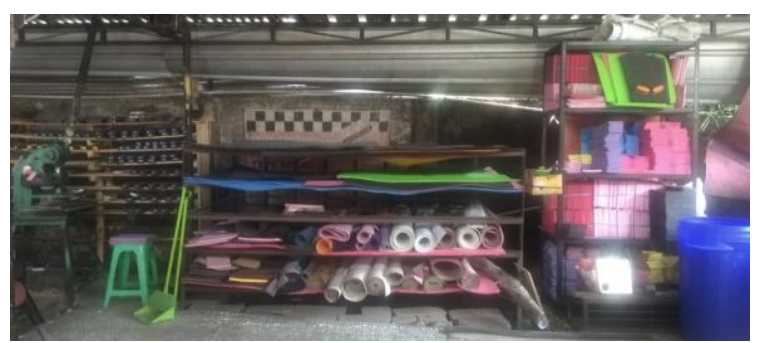

Gambar 7. Penyimpanan Bahan Baku Setelah mengikuti Program SCORE UNPAR

Dapat terlihat perubahan secara signifikan pada Gambar 6 dan Gambar 7, perubahan secara langsung dapat dirasakan oleh perusahaan, dan telah terjadi eliminasi pemborosan dan peningkatan efisiensi waktu kerja karena tidak ada waktu yang terbuang untuk mencari bahan baku.

\section{SIMPULAN}

Pelaksanaan SCORE UNPAR batch 4 telah berjalan dengan baik, namun kondisi pandemi COVID 19 membuat pelaksanaan tidak berjalan secara ideal, namun penyesuaian telah dilakukan sebaik mungkin dengan penuh pertimbangan. Perubahan metode secara mendadak menyebabkan beberapa peserta tidak dapat beradaptasi dengan metode online, baik karena keterbatasan peralatan maupun keterbatasan pengetahuan.

Dalam kondisi pandemi COVID19 yang belum berakhir ini, penguatan materi pemanfaatan teknologi digital menjadi sangat krusial. Selain itu UMKM yang ada sangat membutuhkan materi pelatihan mengenai Business Continuity selama dan pasca Pandemi COVID 19.

\section{UCAPAN TERIMA KASIH}

Tim Pengabdi mengucapkan terima kasih kepada:

- LPPM Universitas Katolik Parahyangan yang telah mendanai melalui Hibah Pengabdian bagi Pembangunan Masyarakat dengan nomor perjanjian III/LPPM/2020-01/17-PM;

- PPKM (Paguyuban Pengusaha Kecil Menengah) Kabupaten Bandung;

- Para Pemateri workshop SCORE yaitu: Fernando Mulia, SE., M.Kom.; Dr. Judith F. Pattiwael, Dra., MT.; Triyana Iskandarsyah, Dra., MSi.; Irsanti Hasyim, SE., MM., M.Eng.; Rizka Nugraha Pratikna, SE., MM.; V.J. Wisnu Wardhono, Drs., M.SIE; Catharina Tan Lian Soei, Dra., MM.; Brigita Meylianti S., Ph.D.; Dr. Istiharini, SE., MM.

- Para Coach yang telah mendampingi peserta Program SCORE UNPAR Batch 4 yaitu: Atty Yuniawan, SE., MBA., CMA; Lilian Danil, SE., MM.; Nina Septina, SP., MM.; Dr. Sylvia Fettry EM, SE., SH., M.Si.Ak.; Fernando Mulia, SE., M. Kom.; Dr. Judith F. Pattiwael, Dra., MT.; Triyana Iskandarsyah, Dra., MSi.; Irsanti Hasyim, SE., MM., M.Eng.; Rizka Nugraha Pratikna, SE., MM. 
- Para Mahasiswa yang juga ikut dalam pengabdian ini.

\section{REFERENSI}

[1]Adriani, L. R., Iskandarsyah, T., Sugiharti, A., Irawan, J. F., Septina, N., Pratikna, R. N., . . . Yuniawati, A. (2018). Efektivitas Program SCORE UNPAR dalam Revitalisasi Bisnis UKM. (J. F. Irawan, Penyunt.) Bandung: UNPAR PRESS.

[2]Humas Pemkab Bandung. (2017, January 25). Paguyuban UKM Kab. Bandung Segera Dibentuk. Dipetik April 30, 2021, dari Website Resmi Pemerintah Daerah Provinsi
Jawa Barat: https://jabarprov.go.id/index.php/news/2100 3/2017/01/25/Paguyuban-UKM-KabBandung-Segera-Dibentuk\#

[3]International Labour Organization. (2020). The Catholic Parahyangan University Implementation partner for ILO SCORE Training in West Java. Jakarta: International Labour Organization. Diambil kembali dari https://www.ilo.org/global/docs/WCMS_74 6051/lang--en/index.htm

[4]SCORE Indonesia. (2021, April 20). Tentang SCORE. Dipetik April 30, 2021, dari SCORE Indonesia: https://scoreindonesia.net/sekilas-score/ 